\title{
Character Education Model of Students in State Islamic Senior High School (MAN) I Medan City
}

\author{
Ahmad Darwis ${ }^{1}$, Al Rasyidin ${ }^{2}$, Saiful Akhyar Lubis ${ }^{2}$ \\ ${ }^{1}$ Ph.D Student in State Islamic University of North Sumatera (UINSU), Medan, Indonesia \\ ${ }^{2}$ Lecturer in State Islamic University of North Sumatera (UINSU), Medan, Indonesia \\ ahmad_darwis2001@yahoo.com
}

\begin{abstract}
The aim of this study is to find and develop a character education model for MAN students throughout Medan City. Due to the extent of character education, the researchers limit character education in the learning process of cooperative learning-based because these model is more appropriate in student character education. This study is conducted by using Research and Development approach. The conclusions of this study are 1) the character education model has been carried out and developed that still using the communicative method more. 2) The results of the analysis show an increase in the results of character education, seen from the activities of student activities. 3) The development of the character education model of students in State Islamic Senior High School (MAN) throughout Medan City is still being carried out normally, through the $R \& D$ research, the overall learning phase can be carried out well using the Learning Design with a cooperative learning approach.
\end{abstract}

Keywords : character education; learning model; students.

\section{Introduction}

Character education of students at MAN 1 Medan through learning activities is more than extra-curricular activities. Character education if seen from the program activities carried out in MAN 1 Medan city has been running, both in the form of rules, facilities and infrastructure as well as extra-curricular activities. But character education in the implementation of learning has not been seen, the learning process is still done traditionally.

To shape the students character in MAN 1 Medan city, there needs a character education model of student mainly through learning activities so that it can help students become independent students, and can improve student academic achievement, cooperative learning models which are also an alternative models for traditional models that contain full teaching with various instructions from educators. With the cooperative learning model, students are actively involved with other students and learning material. The successful implementation of this model is an activity or program that must be planned, organized, and structured with tasks related to the objectives of learning.

\section{Review of Literatures}

\subsection{Character Education}

Linguistically, characters are the mental and moral characteristics that distinguish a person from another person or nature. The word character is derived from English character, which means character, role, and letter. The karakter has become Indonesian and furthermore from the Greek charassein which means "to carve out a pattern that remains indelible" so that in terms of terminology, character" is a combination of all human nature that is permanent so it becomes a special sign to distinguish one person from another ".

Character means good behavior, which distinguishes it from 'nature' which is interpreted as bad behavior. Character is "a collection of good behavior from a human child, this behavior is a manifestation of the awareness of carrying out the roles, functions, and duties to carry out 
the mandate and responsibility", while the opposite character indicates "a number of bad temper a person". In the formation of humans, according to Sudewo, the role of character cannot be set aside, in fact it is this character that places a person's good or bad. The position of character is not a competency companion, but rather a basis, spirit, or soul. Furthermore, without the character of self-improvement from competence can go wild, walk without signs and rules.

Character is often also associated with personality, so the formation of character is also associated with the formation of personality or behavior. So the character is a collection of the good behavior of someone who is done with awareness and full responsibility.

\subsection{The Purpose of Character Education}

Education aims to make humans continue to grow as main-minded beings as their true identity. Article 3 of the National Education System Law No. 20/2003 states: "National education function is to develop and shape the dignified character and civilization of the nation in the context of developing the intellectual life of the nation, aiming at developing the potential of students so that they become human faithful and devoted to God Almighty, noble, healthy, knowledgeable, capable, creative, independent, and become citizens who are democratic and responsible ". From this national goal, a complete human figure is drawn, both spiritual and moral intelligence, emotional and aesthetic intelligence, intellectual and professional intelligence, and social and functional intelligence.

Education wants to develop the potential of students as a whole, not only the intellectual dimension but also the spiritual, character, kinesthetic, social, and skill dimensions. Basically education seeks to foster the potential and personality of students so that they become intelligent, noble and have skills that are useful for themselves, their families, communities, nations and countries.

\subsection{Character Education in Islamic Perspective.}

Character education has the same orientation as moral education that is the formation of personality. If so far character education has been successfully formulated by its activists to the very operational stages including methods, strategies and techniques, while moral education is loaded with information on ideal criteria and sources of good character, then combining the two into a very inspiring offer. This is also the first step that character education has a strong bond with the values of spirituality and religion.

In Islamic terminology, the definition of character has a close understanding with the definition of "morals". The word morals comes from the word khalaqa (Arabic) which means temperament, character and customs. According to the etymological approach, the "moral" approach is derived from the plural Arabic form of its mufrad "Khuluqun" (خلق) which according to the accent is interpreted as character, temperament, behavior or character. This sentence contains aspects of correspondence with the words "khalkun" (خلق) which means event, and is closely related to "khaliq" (خالق) which means creator and creature (مخلق) which means created.

The moral definition above appears as a mediator of communication between the Creator and the reciprocal creature which is then called hablumminallah. From the verbal hablumminallah was born the pattern of relationships between human beings called hablumminannas. 


\section{Research Methods}

This research method uses Research and Development (R\&D). Research and Development is a series of processes or steps in order to develop a new product or improve existing products in order to be accountable.

In the field of education produced through Research and Development stated by Sugiono there are educational products such as specific curricula for specific educational needs, learning methods, instructional media, textbooks, modules, educational staff competencies, evaluation systems, competency test models, spatial planning classes for specific learning, production unit models, workshops models in learning, etc. The final result of research and development activities is the design of new products, complete with specifications, which are manifested in drawings and charts, so that they can be used as a guide to assessing, creating and implementing it. $^{1}$

This study was conducted in State Islamic Senior High School (MAN) throughout Medan City specifically at MAN 1 which is located on Jl. Williem Iskandar, No. 7B, Medan, Indonesia.

In modern terms, it emphasizes differences and individuality which tends to equate the term character with personality. Personality can be understood as a dynamic organization in individuals where the psychophysical system determines unique adjustments to their environment.

\section{Discussion}

\subsection{The Implementation of Character Education in MAN 1}

In the study, researchers conducted interviews about the implementation of Character Education.

1. Interview with Head of State Islamic Senior High School (MAN) 1 Medan Mr. H. Ali Masran Daulay, M.Pd on November 3, 2015.

a. Character Education Planning:

Character education is planned by the principal of School, Deputy Head of School, KTU and Staff, and the School Committee. The principal in implementing the character education planning by improving management and preparing to launch CCTV 16 channels throughout MAN 1 Medan to monitor how the student's character education process.

b. The Implementation of Character Education:

The implementation of character education is carried out by the Head of School, Deputy Head of School, teaching staff and School Committee.

c. The Evaluation of Character Education:

The evaluation of character education is carried out every month that is in each semester by involving the deputy head of School and security.

2. Interview with WKM of Student Affairs Drs. Sunariyadi on November 3, 2015.

a. Contributions implemented in character education are:

\footnotetext{
${ }^{1}$ Sugiono, Metode Penelitian Kuantitatif, Kualitatif dan R\&D, Bandung: Alfabeta, 2012). pp. 412-413
} 
Implementing the extra-curricular activities, move students to be disciplined, give understanding to students who are able to help their friends who are unable.

b. Evaluation of Character Education is implemented:

Every month by giving reports on extracurricular activities, accompanying reports on extra-curricular activities for teachers, and alumni.

3. Interview with Counselor Mr Drs. Amir Husin Pangaribuan, M.Pd, Cons on November 3, 2015.

a. Contributions in students' character education:

Providing services to students, if students are late picket may not repatriate students but told to memorize 5 verses, then communicate with parents, call parents, cooperate with teachers on student homework and provide information to parents about students.

4. Interview with Aqeedah Moraqa Teachers, Mr. Rahmad Jamil M.Pdi, November 4, 2017

a. Developing the Learning Process with students' Character Education:

Explain examples of material by developing lesson plans integrated with student characters, as well as the subject of aqeedah morals related to the character traits of praiseworthy traits, exemplary Prophet and Apostle integrated with student characters.

5. Interview with student Annisa Nurmalasari Hsb (XII IPA) on November 4, 2015.

a. Character values given by the teacher to students:

Dress well, talk well, keep clean and tidy and provide a complete set of learning tools.

\subsection{Discussion in Interview Results of Students' Character Education in MAN 1 Medan 4.2.1. Character Education Planning}

From the interview and observation data above, it can be seen that MAN 1 Medan has implementing the character education planning in which the stakeholders are actively participating in contributing for character education. Character education planning conducted in MAN 1 Medan is planned by the school principal, deputy headmaster, KTU and staff, and the school committee. Principals in making character education planning by supervising properly that is completing facilities in order to improve management as the principal of school and preparing to launch CCTV 16 channels throughout MAN 1 Medan to monitor how the character education process of students. So that all activities in the process of teaching and learning activities as well as extra-curricular activities and all activities of students, employees can be supervised and monitored properly.

\subsubsection{Implementation of Character Education}

From the results of interviews and observations it can be seen that the implementation of character education is carried out by the school principal, deputy of headmaster, teaching staff and school committee. The implementation of character education in learning activities only uses the communicative method.

\subsubsection{Evaluation of Character Education}

From the results of interviews and observations conducted by researchers, it can be seen that the evaluation of character education is done every month that is in each semester by involving the deputy of school headmaster and security. Likewise, the results of interviews with the Deputy of school headmaster in Student Affairs can be seen that the Evaluation of Character Education is done every month by giving reports on extracurricular activities, reports on Accompaniment of extracurricular activities, both teacher's assistant, and alumni assistant. 


\subsection{Results of the Development of Education Character Models of Cooperative Learning- Based}

\subsubsection{The Model of Students' Character Education Design Learning of Cooperative Learning-Based}

The model of student's character education in MAN throughout Medan City should be implemented by referring to the signs or curriculum that exist in MAN throughout Medan. This guideline was issued and established by MAN institutions.

Based on these signs, researchers develop models that are nuanced or based on the Cooperative Learning approach. The results are as follows:

a. The five elements that must be considered in cooperative learning, are as follows:

1) Interdependence,

2) Individual responsibility,

3) Face to face

4) Communication between members.

5) Evaluation of group processes

b. Class management is developed by:

1) Grouping, in this grouping is carried out when participants explore the material and teaching assignments given by the teacher to participants. The application is in group discussions and games.

2) Mutual cooperation, the values of mutual cooperation in the activities of giving responsibility.

3) Spatial planning, learning space when learning is done in class and some outside the classroom. Likewise there are activities in class time that are placed in groups.

c. Learning strategies / methods are developed by choosing three forms namely;

1) Think Pair Share.

2) CIRC

3) Jigsaw

Think Pair share is defined by thinking, pairing and sharing. The resource person gave a discourse by way of a percentage in front of the class, from the discourse delivered several problems to be solved or answered. Then participants individually think of the answers and the results can be stored in the mind but better in written form. Participants are asked to pair up to discuss answers obtained on their own time. The next step the participants were asked to join several people to form a new group. In the new group the participants answered the initial questions by having a discussion that was followed by all members in the group.

The development of this Think Pair Share strategy is to find a partner. Looking for a partner is one of the techniques in cooperative learning. This technique was developed by Lorna curran (1994) where the advantage is that the participants are mentally and physically active to get a partner and knowledge. The steps are:

a. The teacher prepares several cards that contain parts of the material to be delivered.

b. Each student gets one card

c. The next time each student is asked to look for a pair of cards from an appropriate friend or one type, or a group of cards that he has.

d. The number of groups varies, there are three, four, five, six and so on.

e. After the participants have grouped, they formulate objectives, a description of the results of the group and then present it to the class. 
f. At each percentage, other groups or individually from other groups are given the opportunity to provide responses and rebuttal. The ability of individuals to convey responses and rebuttal is made part of cooperative learning assessment.

CIRC stands for Cooperative Integrated Reading and Composition. In this type of learning students are divided into groups which are then given assignments either in the form of reading material or other assignments. Each group was asked to review or conclude the reading material in accordance with the ability of each group.

Jigsaw is one of the techniques in cooperative learning. Initially this technique was developed to train students in reading, writing, listening and speaking. The aim of this technique is for participants to have the ability to communicate and then convey the knowledge they have to others. The technical steps are as follows:

a) Form groups of students

b) Determine the material to be discussed for each group.

c) Ask each group to appoint one person to be the group's spokesperson.

d) Ask each group to discuss the material according to the topic.

e) Ask the spokesperson to present the results.

f) Spokespersons come forward.

g) Evaluation Model

The evaluation model or in this case also called assessment in cooperative learning-based training is based on the meaning of the philosophy of the spirit of cooperation, and individual responsibility. For this reason, the assessment is based on group assignments, where the final result or group score will contribute to the individual score.

In this study the assessment is more aimed at the level of individual participation in the group, then the ability to work together be it accepting other people's opinions or group opinions. The evaluation is more up to the teacher who has already had a form in the attachments to the worksheet model.

\subsubsection{Formulation of Cooperative Learning Design}

This design model is an initial draft to later be developed and implemented in learning activities in MAN throughout Medan city. The initial model is as follows:

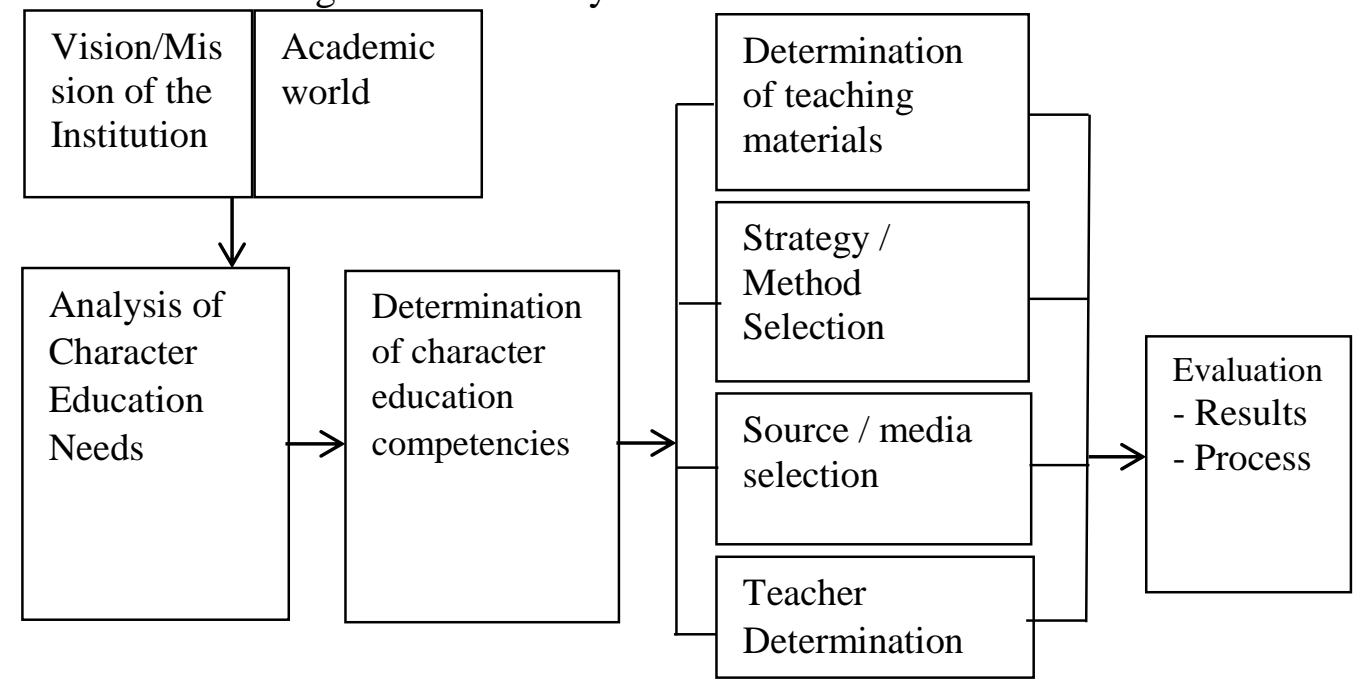

Figure 10. The Model of Students' Character Education Design Learning of MAN throughout Medan City 
Model description are as follows:

This learning model is a form of design activities regarding the development of learning in MAN throughout Medan. The purpose of this model is to be able to provide guidance and guidance for teachers in planning, managing, developing, and evaluating cooperative learning based learning activities.

The main components of this character learning model consist of:

a. Analysis of learning needs.

b. Determination of learning competencies

c. Determination of teaching materials.

d. Strategy / method selection.

e. Teacher designation.

f. Evaluate results and process

All of these components do not stand alone but constitute a systematic unit in the development of a learning model.

\section{a. The First Stage is the Analysis of Learning Needs}

It is an activity of identifying the share of institutional needs that will be implemented in the form of goal formulations, then to be developed in learning activities. In this study, of course, limited to the analysis of the needs of learning models with the needs of MAN students throughout Medan.

After conducting observations and interviews through questionnaires to students the need for character education materials that students need in MAN throughout Medan is:

1) Religious or faith material

2) Honest attitude

3) Responsibility

4) Discipline

5) Fair attitude

6) Tolerance

7) Attitude of affection

8) Attitude to maintain honor

9) Trustful attitude

10) Patience

11) Wise attitude

12) Forgiveness

13) Attitude to fulfill promises

14) An attitude of holding back anger

15) Tawadhu attitude

Purposes:

In order to get the right input in terms of developing the character of School students as well as in accordance with the learning characteristics of MAN students throughout Medan city.

Main component:

1) School vision

2) School mission

3) School work program

4) Input characteristics (students) 
5) The tendency of educational institutions

Development Form:

1) Ask the chief character education expert

2) Discussion with the Principal / Teacher

b. The Second Stage is determination the Competency of Character Education Learning

The competencies are determined according to the needs of students and what are the goals of education and in accordance with the vision and mission and goals of an institution.

This second stage is the activity of compiling competencies that become the final destination for students after participating in learning in MAN throughout the Medan city. Purposes:

1) General Learning Objectives.

In formulating the general objectives of character education learning the teacher must formulate the character education of students in the learning process and develop the material and objectives to be in accordance with current conditions and refer to the Al Qur'an and Al Hadith.

2) Specific objectives per subject.

Specific objectives per subject are expected so students can: a). Appreciate and live the religion they profess. b). Respect and appreciate the values of character in life. c). Understanding knowledge based on curiosity about science. d). Trying, processing, and presenting in the realm of concrete (using, decomposing, stringing, modifying and creating) and abstract shutter (writing, reading, calculating, drawing, writing) in accordance with what is learned in Schools and other sources that are the same in theory.

3) The purpose of each activity session.

The purpose of each activity session is expected so that students can explain the material delivered on the subject matter invited by each activity session.

4) Completeness of ABCD (Audience, Behavior, Conditioning, and Degree).

Audience is students as objects that are targeted in learning activities. In formulating learning objectives it should be seen how students' activities to understand subjects taught by the teacher. Behavior is the behavior or behavior or activities of students in learning, learning without student behavior is not possible. Activities of students listening, listening or other processes, activities that are expected from students are to be adapted to the context of the material content. Conditioning is defined as a state, condition. In this case the condition / condition of students before and after participating in activities, the requirements that need to be met so that the expected behavior can be achieved. Learning is a change in behavior so the conditions are very basic. Under what circumstances the learning process occurs. Degree means comparison / comparison, in the context of learning objectives aimed at comparing conditions before and after learning. The degree level depends on the weight of the material to be presented through the learning objectives. The degree must also relate to the type of behavior change students will display.

5) Logical sequence of the objectives of character education learning.

The order of learning objectives refers to the basic competencies that will be achieved in learning as a reference that starts from the selection of the type of material, strategies, methods, and learning media that will be used in the learning process.

Development form

1) Ask the Teacher 
2) Asking leaders / leaders MAN

3) Discussion with School Employees

\section{c. The Third Stage is the Determination of Character Education Teaching Materials}

Activities compile teaching materials that will be delivered in character education learning to achieve competence or the objectives of character education learning activities for MAN students throughout Medan. It should be emphasized that the learning material has been arranged in a curriculum set by Schools. However, the curriculum can be used as a guide for the development of materials used in character education.

Before developing the Character Education Model researchers conducted research and observations about the initial conditions of learning character education for MAN students throughout Medan.

Before an analysis of the character education learning process is carried out in class, the researchers first present it in the form of the existing learning process, the researchers obtained data from the syllabus and learning unit (SAP) used by MAN teachers throughout Medan in the learning process all this time.

Syllabus and SAP used by teachers so far, consists of competency components students are able to understand about character science that is the minimum ability that students must obtain after the learning process takes place, for example students can explain about character science.

Indicators of achievement of learning outcomes are indicators that show the learning outcomes that have been mastered by students, such as being able to explain and understand the meaning, scope and benefits of learning it.

The subject matter of learning carried out by the character education teachers consists of several materials that have been compiled based on the provisions that have been in effect written by the caregivers of the subject character education subjects that are discussed in the subject of: Perfection of Islamic faith, monotheism, improvement the quality of morals, moral values praiseworthy, despicable morals, morals praiseworthy qana'ah rida patience, morals to parents and teachers, the exemplary story of the Prophet Joseph.

While the subject matter of character / character 1 is:

1. Perfection of Islamic creed

a. Definition of creed

b. Arguments / arguments in creed

c. The aim of Islamic creed

d. Method of increasing Islamic creed

2. Monotheism

a. Definition of monotheism

b. The scope of monotheism

c. Various kinds of monotheism

d. Understanding the meaning of monotheism

e. Wisdom and benefits of tauhid

f. The characteristics of a person with unity

3. The application of methods to improve the quality of morals

a. Understanding morals

b. Various kinds of morals

c. Similarities and differences between morals, ethics, morals and character 
d. How to improve the quality of morals

e. The application of moral quality improvement

4. Moral values are commendable
a. Wisdom
b. Iffah
c. Syaja'ah
d. 'Adalah

5. Valuable moral values
a. Hubbud-dunya
b. Hasad
c. Takabur / ujub,
d. Riya'

6. Appreciation of gratitude, qana 'ah, rida, patience
a. Gratitude
b. Qana'ah
c. Ridla
d. Patient

7. Morals commendable to parents and teachers.
a. Manners towards parents and
b. Be polite to the teacher

8. The main qualities of the Prophet Yusuf a.s.
a. The main character of the Prophet Yusuf a.s when facing trials
b. The main character of the Prophet Yusuf a.s. at glorious time
c. Ibrah from the Story of the Prophet Yusuf a.s.

While the subject matter of character or character sem II are:

1. Avoiding shirk in daily life
a. Rejection of syirik
b. Avoid syirik

2. Asmaul Husna
a. Understanding Asmaul Husna
b. Various kinds of Asmaul Husna
c. Understand the meaning of Asmaul Husna
d. Wisdom and benefits of Asmaul Husna

3. Good character
a. Husnuzzan,
b. Raja'
c. Repentance

4. Despicable morals
a. Sly.
b. Tamak,
c. Wrongdoers
d. Discrimination

5. Good manners when visiting sick people.
a. Manners visit
b. Practicing the morals of sick people 
6. Prophet ulul azmi
a. The Prophets of ulul azmi
b. The main qualities of the Prophet ulul azmi
c. Ibrah from the Story of the Prophet ulul azmi.

\section{d. The Fourth Stage is the Selection of Strategies / Methods of Learning Character Education}

The activity chooses the most appropriate learning strategies and methods to develop character education activities so that the objectives of character education can run effectively and efficiently. Cooperative Learning values are developed in each major selection on the implementation of character education strategies / methods.

In this section, researchers submit a statement that the learning methods used in MAN throughout Medan have been lectures, discussions, and problem solving.

Purposes:

So that character education learning activities can run well and achieve results as expected.

Main component:

1) Accuracy with objectives

2) Conformity with the material

3) Conformity with the psychological level of students

4) Attract student interest

5) Original and up to date

Development Form:

1) Ask a character education expert

2) Discussion with the teacher / School head

3) Ask students

\section{e. The Fifth Stage is the Selection of Media / Learning Resources}

The fifth stage is the activity of identifying various media and resources that can be used, used for the management of character education activities for MAN students throughout Medan.

The learning media that are used in MAN throughout Medan are blackboard, LCD, OHP. Purposes:

So that the implementation of character education runs optimally with the support of media facilities and learning resources.

Main component:

1) Compliance with objectives

2) Conformity with the material

3) Ease of obtaining / access

4) Ease to use

5) Cost efficiency

Development Form:

1) Ask a character education expert

2) Discussion with the teacher

3) Discussion with employees / leaders of Schools 


\section{f. The Sixth Stage is the Determination of the Teacher}

The sixth stage is the activity of identifying some of the competencies and criteria desired to become a teacher implementing character education learning for MAN students in the city of Medan. Teachers are formed in a team to develop the values of Cooperative learning Purposes:

In order to get qualified teachers in accordance with the desired standards for their abilities in developing character education learning models.

Main component:

1) Insights for character education

2) School Commitments

3) Communication

4) Teamwork ability

5) Creativity

Development Form:

1) Ask a character education expert

2) Discussion with School leaders

\section{g. The Seventh Stage is the Evaluation of Results and Processes}

The seventh stage is the activity of measuring the assessment of character education learning both to the learning process carried out and the students who take part in the learning. Measurement of success is based on developing cooperative learning values

Purpose:

To get the right input of data and information about the achievement of the objectives of character education learning as well as feedback for further learning improvement.

Main component:

1) Learning objectives

2) Summarize all subjects

3) Covers all aspects of cognitive, affective, and psychomotor.

4) Accuracy of evaluation forms.

5) Providing feedback.

Development Form:

1) Ask a character education expert.

2) Discussion with the teacher.

\section{h. Vision and Missions of State Islamic Senior High School (MAN) 1 Medan.}

Vision: Excellent and Populist Achievement in the Science and Technology Frame and Imtaq Mission:

1) Increase the noble character of students

2) Increase the practice and delivery of Islamic teachings

3) Prepare students to continue their education to Higher Education

4) Improving students' skills, independence and productivity in accordance with the study program being studied.

5) Prepare students to be able to answer the demands of society. 


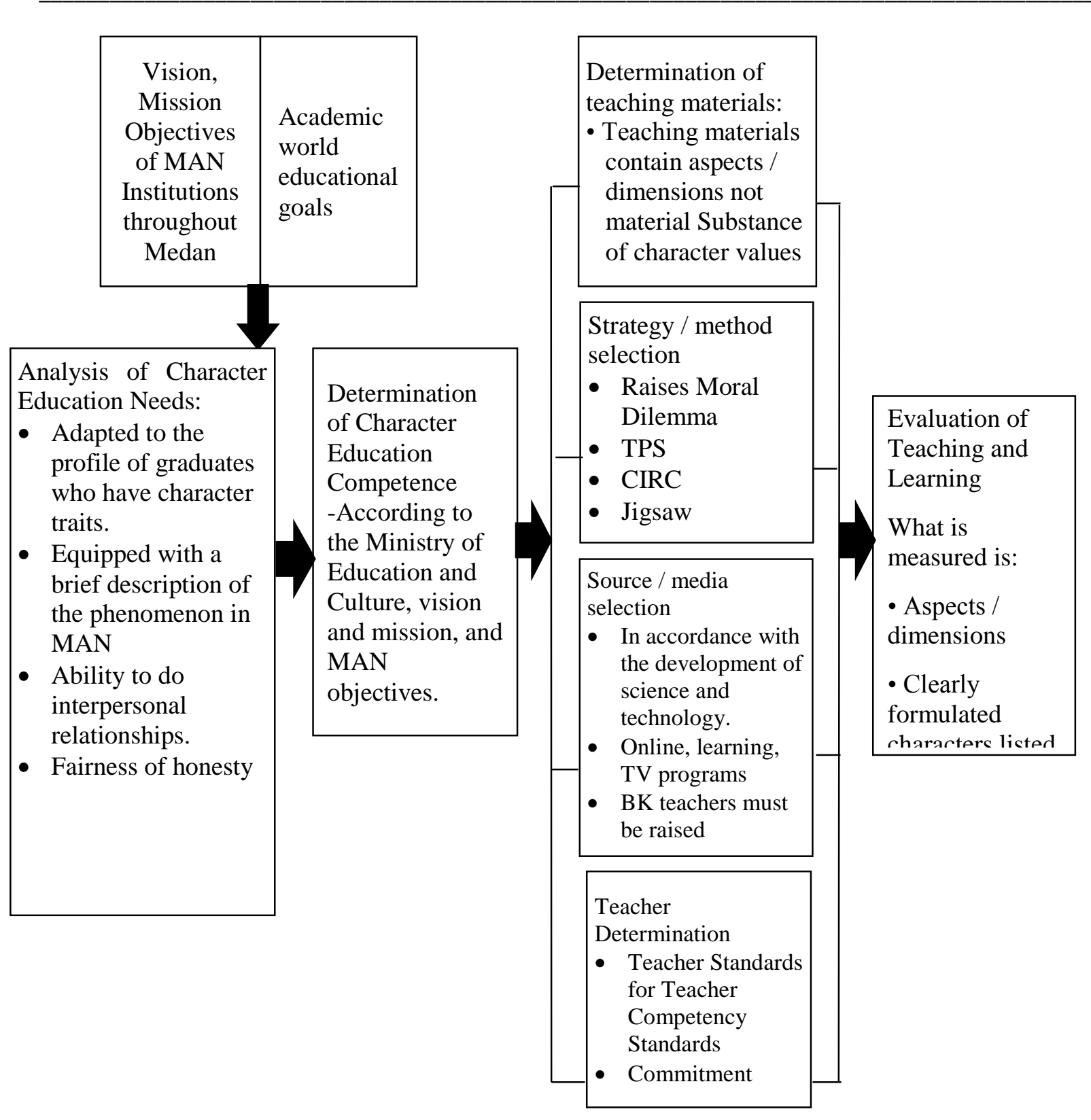

Figure 11. The Students' Character Education Design Model of MAN in Medan City.

\section{Conclusion}

In general, this study aims to find and develop character education models for MAN students throughout Medan City. Due to the extent of character education, the researchers limit character education in the learning process of cooperative learning-based because these model is more appropriate in student character education. Specifically this study provides the following conclusions:

1. In general, teachers in MAN throughout Medan have conducted character education. The character education model that has implemented and developed is still using the communicative method. 
2. Assessment is done both descriptively through observation, and interviews. The analysis showed an increase in the results of character education, seen from the activities of student activities.

3. The development of the character education model of students in State Islamic Senior High School (MAN) throughout Medan is still being carried out normally, and through the R\&D approach, through the R\&D research, the overall learning phase can be carried out well using the Learning Design with a cooperative learning approach.

\section{References}

Ahmad, Muhammad Al Hufy, Akhlak Nabi Muhammad saw (Keluhuran dan Kemuliaannya), Alih bahasa Masdar Helmy dan Abd Khalik Anwar, Jakarta: Bulan Bintang, 1978.

Agus, Suprijono, Cooperative Learning, Teori dan Aplikasi Paikem, Print IV, yogyakarta : Pustaka Pelajar, 2010.

Al Ghazali, Mengobati Penyakit Hati Membentuk Ahklak Mulia, translated by Achmad Sunarto, Bandung: Kharisma, 1994, Print. 1.

Abdullah, Sulaiman bin, Inilah Islam Sumber, Karakteristik dan Keistimewaan, Bekasi : Sukses Publishing, 2011.

AR, Zahruddin and Sinaga,Hasanuddin, Pengantar Studi Akhlak, Jakarta : Rajawali, 2004.

Adisusilo, Sutarjo, J.R, Pembelajaran Nilai Karakter Kontruktivisme dan VTC Sebagai Inovasi Pendekatan Pembelajaran Afektif, Jakarta: PT Raja Grafindo Persada, 2013.

Asifin, Jalan menuju Ma'rifatullah dengan Tahapan (7 M), Surabaya : Terbit Terang, 2001. Arikunto, Prosedur Penelitian, suatu Pendekatan Praktek, Jakarta: Rineka cipta, 2010.

Bruce, Joyce, \& Weil, Marsha. Model of Teaching, United State of America: Allyn \& Bacon A Pearson Education Company, 1992. , Quoted by Zamsiswaya, Pembelajaran dengan Menerapkan Ideologi Lima-I, Pekan baru: lembaga penelitian dan pengembangan UIN SUSKA Riau, 2012.

Baqir sharif al qarashi, seni mendidik islami: kiat-kiat Menciptakan generasi Unggul. Translation, Jakarta: Pustaka Zahra, 2000.

Cepi, Dharma Kesuma, Triatna and Johar Permana, Pendidikan Katakter (Kajian Teori dan Praktik di Sekolah), Bandung: Remaja Rosdakarya, 2011.

Caroline, Laws, Sophie. Harper, \& Rachel, Marcus. Research for Development A Practical Guid, London: Sage Publication 2011.

Djamarah, Syaiful Bahri and Zain, Azwan, Strategi Belajar Mengajar, Jakarta: PT. Asdi Mahasatya, 2010.

Hariyanto, Warsono, Pembelajaran Aktif : Teori dan Asesmen, (Bandung : PT Remaja Rosydakarya, 2012)

Jejen Mustafa (Ed), Pendidikan Holistik; Pendekatan Lintas Persfektif Jakarta: Kencana Prenada Media Group, 2012.

, Pendidikan holistik Pendekatan Lintas Persfektif Jakarta: Kencana Prenada Media Group, 2012.

James, M. Hutabarat, Ilmu Administrasi, Yogyakarta: Liberty, 1988.

Jim, Stewart, Managing Change Through Training and Depelopment: Mengelola Perubahan Melalui Pelatihan dan Pengembangan, Alih bahasa: Justinus Agus Budi, Jakarta : Gramedia Pustaka Utama, 1997. 
Kementrian Pendidikan Nasional Badan Penelitian Pengembangan Pusat Kurikulum, Badan Pelatihan Pengembangan Pendidikan Budaya dan Karakter Bangsa, Jakarta: Kemendiknas, 2010.

Khan, Yahya, Pendidikan Karakter Berbasis Potensi Diri, Yogyakarta: Pelangi Publising, 2010.

Kartono, Kartini, Teori Kepribadian Bandung : Mandar Maju, 2005.

Khalid, Amru, Semulia Akhlak Nabi Saw, Penerjemah Imam Mukhtar, Lc, Solo: Aqwam, 2006. Louis Ma'luf, Al Munjid, Beirut : al Maktabah AL-Katulikiyah, tt.

Lickona,Thomas, Educating For Character Mendidik Untuk Membentuk Karakter Bagaimana Sekolah Dapat Mengajarkan Sikap Hormat dan Tanggung Jawab, Penerjemah Juma Abdu wamaungo Jakarta : PT Bumi Aksara, 2013.

, Character Matters (Persoalan Berkarakter) Bagaimaan membantu Anak mengembangkan penilaian yang Baik, Integritas dan kebajikan lainnya, Translated by Juma Abdu Wamaungo \& Jean Antunes Rudolf Zien, Jakarta : PT Bumi Aksara, 2012.

Lubis, Mara Samin, Telaah Kurikulum Sekolah Menengah Umum/Sederajat, Bandung : Citapustaka Media Perintis, 2011.

Lou, Dick, Walter. Carey, \& Carey, O. James. The Systematic Design of Instruction. United States: Addison-Wesley Educational Publishers Inc, 2001.

Muslih, Masnur, Pendidikan Karakter Menjawab Tantangan Krisis Multidimensional Jakarta: Bumi Aksara, 2011.

Muhammad, Athiyah Al-Abrasyi, Prinsip-Prinsip Dasar Pendidikan Islam, Penerjemah Abdullah Zakiy Al-Kaaf, Bandung: CV Pustaka Setia, 2003. , Prinsip-Prinsip Dasar Pendidikan Islam, Terj Abdullah Zakiy Al-Kaaf, Bandung: Pustaka Setia, 2003.

Mustafa, Jejen (Ed), Pendidikan Holistik; Pendekatan Lintas Persfektif, Jakarta : Kencana Prenada Media Group, 2012.

Mathew B, Miles, \& Huberman, Michael A. Analisis Data Kualitatif. Penerjemah Tjejep Rohendi Rohidi. Jakarta: UI Press. 1992.

Naim, Ngainun, Carakter Building: Optimalisasi Peran Pendidikan dalam Pengembangan Ilmu \& Pembentukan Karakter Bangsa, Jakarta: Ar Ruzz Media, 2012.

Nata, Abuddin, Akhlak Tasawuf, Jakarta : Rajawali Pers, 2009.

Ramayulis, Ilmu Pendidikan Islam, Jakarta: Kalam Mulia, 2002.

Raka,Gede, Tim Pakar yayasan Jati Diri Bangsa, Pendidikan Karakter di Sekolah, Jakarta : PT Kompas Gramedia, 2002).

Rusman,Model-Model Pembelajaran : Mengembangkan Profesionalisme Guru, Edisi Kedua ( Jakarta :Rajawali Pres, 2012.

Megawangi, Ratna, Pandidikan Karakter: Solusi Tepat Untuk Membangun Bangsa, Bogor: Indonesia Heritage Foundation, 2004

Dewi, Salma, Prinsip Desain Pembelajaran, Print II, Jakarta: Kencana,2008.

Zainal Aqib, Pendidikan Karakter di Sekolah ; Membangun Karakter dan Kepribadiaan Anak, Bandung : CV. Yrama Widya, 2012.

Daradjat, Zakiah, Ilmu Pendidikan Islam, Jakarta : Bumi Aksara, 2004.

Zuchdi, Darmiyati, Humanisasi Pendidikan : Menemukan Kembali Pendidikan Yang Manusiawi, Jakarta : Bumi Aksara, 2008.

Zuriah, Nurul, Pendidikan Moral Dan Budi Pekerti Dalam Persfektif Perubahan, Jakarta: Budi Aksara, 2007. 